\title{
A importância das infraestruturas de transporte para o desenvolvimento industrial brasileiro: um enfoque Rangeliano para superação da crise atual
}

\author{
Nilmar Rippel ${ }^{1}$ \\ Alessandro Viceli ${ }^{2}$ \\ Eduardo Von Dentz ${ }^{3}$
}

\section{RESUMO}

Este trabalho tem por objetivo apontar a interpretação de Rangel, acerca da crise da dívida nos anos 1980 via concessão dos serviços de utilidade pública à iniciativa privada, ressaltando a importância simbiótica entre as infraestruturas de transporte e o setor industrial com vistas à superação da crise atual. O artigo demonstra, que é imprescindível considerar a importância do setor de transportes - no caso em particular os modais rodoviário e ferroviário - para o desenvolvimento econômico brasileiro. Pode-se dizer, que os principais resultados encontrados foram a potencialidade dos investimentos no setor, como sendo estratégicos para alavancagem industrial, o restabelecimento do emprego e consequentemente uma nova fase de crescimento, tendo em vista os efeitos multiplicativos em escala crescente e ampliada em todo o país. Ressalta-se também, a implementação Programa de Aceleração do Crescimento (PAC) a partir de 2007 e a necessidade de continuidade dessas políticas econômicas para a superação da crise atual. Metodologicamente o artigo foi construído através da revisão bibliográfica, levantamento de dados e trabalhos de campo.

Palavras-Chave: desenvolvimento econômico; infraestrutura de transportes; industrialização.

\section{The transportation infrastructure importance to the brazilian industrial development: Rangeliano focus to the current crisis overcoming}

\begin{abstract}
This work have the objective point the Rangel's interpretation about debt crisis in the 1980s via concession of the utility services to private initiative, highlighting the symbolic importance between the transport facilities and industrial sector in order to current crisis overcoming. The article demonstrate that is indispensable consider the transport sector importance - in the case of road and railway - to the Brazilian economic development. It can be said that the main results found were the investments potential in the sector, as being strategic to industrial leverage, the employment reestablishing and consequently a new growth phase, bearing in mind the effects multiplicative in increasing scale and expanded in nationwide. Emphasize the Growth Acceleration Program (PAC) as of 2007 and the need for continuity these economic policies to the current crisis overcoming. Methodologically the article was constructed through of the bibliographic review, data collection and fieldwork.
\end{abstract}

Keywords: economic development; transportation infrastructure; industrialization.

\section{INTRODUÇÃO}

Pensar e escrever sobre as ideias de Ignácio Rangel é uma tarefa relativamente complexa. Sem sombras de dúvidas, o mesmo conseguiu atingir, como poucos, uma precisão sobre os fatos sociais, políticos e econômicos do Brasil. Muitos intelectuais ${ }^{4}$ o consideram como o maior

\footnotetext{
${ }^{1}$ Mestre em Geografia Pela Universidade Estadual do Oeste do Paraná - UNIOESTE. Professor da Rede Estadual de Ensino do Paraná.

${ }^{2}$ Mestre e Doutorando em Geografia pela Universidade Estadual do Oeste do Paraná - UNIOESTE.

${ }^{3}$ Graduado em Geografia - Universidade Federal da Fronteira Sul (UFFS) campus Chapecó. Mestre em Geografia Universidade Estadual do Oeste do Paraná (UNIOESTE) campus Francisco Beltrão. Doutorando em Geografia Universidade Federal de Santa Catarina (UFSC). É professor em regime temporário no departamento de Geografia da Unicentro campus Cedeteg. Email eduardovondentz@ hotmail.com

${ }^{4}$ Ver Armen Mamigonian (2018), Elias Jabbour (2010) dentre outros geógrafos e economistas.
} 
teórico marxista do século XX, o qual desenvolveu um pensamento original. Sobre tais características, Castro (2012, p. 16) afirma que "todos os que escreveram sobre Rangel sublinham, antes de tudo, sua originalidade, sua singularidade teórica". Esses traços fazem tal tarefa se tornar inestimavelmente prazerosa, uma vez que proporciona uma visão de conjunto da sociedade.

Sua macrovisão do processo econômico, conciliado com combinações teóricas, fizeram de seu pensamento um economista à parte dos demais. Bresser Pereira (2006, p. 02), referindo-se sobre as raízes de seu pensamento afirmou que:

As bases do seu pensamento econômico estavam em Marx, Keynes e Schumpeter. Bases sólidas que, submetidas à sua imensa capacidade de enfrentar o pensamento convencional, o lugar comum, as verdades hegemônicas, o tornavam, ao mesmo tempo, heterodoxo e extraordinário. Em muitas ocasiões Rangel desenvolveu ideias que confrontavam o saber convencional. Não apenas o saber convencional dos economistas conservadores, mas também, senão principalmente, dos economistas de esquerda, estruturalistas como ele, ou marxistas.

Essas influências permitiram analisar a economia brasileira através da sua formulação da Teoria da Dualidade Básica, a qual possui um caráter heterodoxo, apesar de transparecer mecanicista, o que, segundo alguns autores, é muito menos mecanicista do que parece à primeira vista (GUIMARÃES, 1994). Nesta teoria, Rangel (1957) busca encontrar a essência do desenvolvimento capitalista brasileiro, ou seja, seu motor primário de desenvolvimento, adaptando teorias clássicas às suas interpretações, incorporando as ideias de que as economias capitalistas, passam por movimentos cíclicos de desenvolvimento.

No entanto, carece demostrar a contribuição teórica da categoria da Dualidade Básica, para assim, entender a dimensão econômica e social da realidade brasileira. Com isso, faremos um esforço para demostrar que Rangel não tratava as questões de forma isolada em sua obra, tendo em vista que essas evidências já eram salientadas por Castro (2012), o qual afirma: “[...] Podemos dizer que qualquer questão que tenha tratado de forma aparentemente tópica - e ele nunca tratava nada de forma realmente tópica - é uma aplicação particular da teoria da dualidade", além disso, segundo Bresser-Pereira (2006, p. 6) seu pensamento segue uma linha ancorada em duas ideias centrais: a teoria da dualidade básica e a dos ciclos longos de Kondratieff.

No decorrer deste texto será demonstrado a importância dos serviços de utilidade pública $^{5}$, enquanto elemento importante para o impulso da retomada do desenvolvimento industrial, lastreado por incremento de mão de obra no processo produtivo e consequentemente o aumento da renda e melhora nos padrões de vida da população. Salienta-se, ainda, que essa questão, além de já ter sido demonstrada por Rangel (1987) em fins dos anos $80^{6}$, continua válida e relevante à discussão. Entretanto, este artigo surge devido ao interesse em contribuir sobre as possíveis estratégias de retomada do desenvolvimento econômico com base na obra de Rangel (1981)

\footnotetext{
${ }^{5}$ Serviços de utilidade pública é entendido como o setor potencial a receber investimentos e a partir disso, capaz de elevar o nível de desenvolvimento econômico e social da sociedade brasileira, por meio do emprego, renda e bemestar social. Como o próprio termo explicita, os serviços de utilidade pública são compostos por toda a infraestrutura social de qual depende um país para se desenvolver, ou seja, são os setores de transportes, energia, saneamento básico, moradia, telecomunicações etc.

${ }^{6}$ A crise dos anos 1980 foi avaliada como um período de somatória algébrica da fase descendente do quarto ciclo de Kondratieff (inaugurada com a crise do petróleo no ano de 1973 e que teve profundos reflexos nas econômias periféricas, como o Brasil, por serem economias importadoras desse produto) com uma crise interna. Esta se expressava como uma crise do padrão de financiamento do setor público, tendo como decorrência o descontrole inflacionário.
} 
Neste sentido, este artigo apresenta a problemática das infraestruturas sob pretensão de que é este setor que continua (dos anos 1980 aos dias atuais) sendo um ponto de estrangulamento, o que impede em certa medida o pleno desenvolvimento econômico do Brasil (MAMIGONIAN, 2004, [2019]). No entanto, é importante estudá-los paralelamente aos recursos ociosos existentes na economia, tendo em vista que é esse setor que possui recursos a serem careados aos setores dos serviços de utilidade pública, por meio de uma estrutura financeira nacional em detrimento de recursos estrangeiros.

Como o setor de utilidade pública é amplo e complexo para ser tratado em um artigo, focaremos apenas nos modais rodoviário e ferroviário. Com isso, verifica-se que o Brasil possui inúmeros problemas nesses modais ${ }^{7}$. No primeiro caso, nota-se que ele é responsável por cerca de $65 \%$ da carga transportada no país ${ }^{8}$ resultando em gargalos nas rodovias públicas, tanto federais quanto estaduais, haja vista, que muitos transportadores optam em não transitar pelas vias concessionadas devido à tarifa ser demasiadamente elevada ${ }^{9}$. As ferrovias por sua vez, possuem defasagem tecnológica, acarretando perda de produtos, no translado até os portos de destino, baixa velocidade média e bitolas não padronizadas, além, é claro, da baixa capilaridade em território nacional. Dessa forma, torna-se latente analisar o setor de infraestrutura enquanto aliado estratégico para o desenvolvimento econômico brasileiro, tendo em vista que tal setor não possui caráter autônomo. Ou seja, considera-se ser um setor reflexo da dinâmica econômica dos demais setores, mas não somente, pois ele pode ser propulsor dinâmico da própria economia brasileira, desde que haja uma clara política industrial a qual leve em consideração o setor de infraestrutura como instrumento chave para o desenvolvimento.

Assim sendo, este artigo divide-se em quatro seções, além desta introdução. Na segunda seção analisaremos a percepção de Rangel (2012 [1987]) em torno dos serviços de utilidade pública, ancorados em elementos de sua teoria da dualidade básica. Na terceira seção, dedicaremos atenção à reciprocidade setorial entre o setor de infraestrutura de $\operatorname{transporte~}^{10} \mathrm{e}$ à indústria e, na quarta e última seção, serão apontadas algumas considerações finais.

\section{A INTERPRETAÇÃO TEÓRICA DE IGNÁCIO RANGEL E A INÉRCIA DOS INVESTIMENTOS NOS SERVIÇOS DE UTILIDADE PÚBLICA NAS DÉCADAS DE 1980 E 1990}

Como seu arcabouço teórico apresenta uma visão histórica e dialética do processo econômico, não é possível discorrer abandonando esse método, uma vez que faz parte da raiz de seu pensamento (RANGEL, 2012, [1957]). Para analisar os serviços de utilidade pública é necessário fazer esse resgate histórico, ancorando tal problemática à teoria da dualidade e aos elementos que estão no cerne dessa teoria, ou seja, aos ciclos econômicos e aos pactos de poder.

Em primeiro lugar, vale apontar que no pensamento de Rangel estava muito clara a percepção de que o Brasil era (e continua sendo) um país periférico, que gravita e responde às vicissitudes internacionais, fazendo eco a seus impulsos, via movimentos cíclicos; fases de expansão "a" e recessão "b". Posto isto, frisamos que a cada momento histórico, a cada conjuntura econômica, existem características fundamentais e específicas a cada crise, exigindo

\footnotetext{
${ }^{7}$ Para maiores esclarecimentos acerca da história dos transportes no Brasil, sugerimos ver Barat $(1978 ; 2007)$

${ }^{8}$ Dados da Confederação Nacional dos Transportes. Disponível em: <https://www.cnt.org.br/agencia-cnt/custologistico-consome-12-do-pib-do-brasil>. Acesso em: 02 fev 2021.

${ }^{9}$ Para maiores detalhes, ver Silveira (2005) o qual afirma que o modelo de concessão ao invés de privilegiar a população e desonerar o Estado, acabou beneficiando as empresas concessionárias em detrimento do bem-estar social.

${ }^{10}$ Boa parte da discussão expressa nesse artigo, é fruto da pesquisa de mestrado intitulada "Recursos ociosos $e$ pontos de estrangulamentos no setor de infraestrutura de transporte no estado do Paraná" defendida no ano de 2021 junto ao Programa de Pós Graduação em Geografia da Universidade Estadual do Oeste do Paraná.
} 
mudanças institucionais. Em outras palavras, podemos dizer que as políticas econômicas viáveis em um determinado período não necessariamente são compatíveis com a aplicabilidade em outros $^{11}$. Dessa forma, são através dessas características que seu pensamento se baliza e se justifica quando elabora suas ideias no texto "O Papel dos Serviços de Utilidade Pública" de 1987.

Pizzo (1998), analisando a visão de Rangel, lembra que o Brasil se desenvolve de forma cíclica e que sob esta perspectiva as conjunturas apresentavam sempre dois componentes: um externo, que nos interligava com o centro dinâmico do capitalismo através dos ciclos longos, e outro interno, que era de média duração e que possuiu sua genese com a industrialização brasileira. Em virtude da sua posição progressista e nacionalista, não fazia alusão em buscar recursos estrangeiros para financiar o desenvolvimento brasileiro, mas muito pelo contrário, tinha a plena convicção de que o capital se faz em casa (NURKSE apud VILLAVERDE E REGO, 2019). Inclusive, ele sempre se preocupava com uma alternativa viável e concreta para as soluções econômicas do Brasil dada a conjuntura, em que não é um fator sine qua non recorrermos aos ajustes fiscais e a grupos financeiros internacionais, como Fundo Monetário Internacional, FED e Banco Mundial, por exemplo. Sobre estas circunstâncias, Rangel (2012 [1987]) questiona:

\begin{abstract}
Devemos consentir no monitoramento de nossa economia pelo fundo monetário internacional (FMI) ou por outras agências financeiras internacionais? A resposta é que não, e isso pelos motivos mais prosaicos do mundo. Não por qualquer veleidade xenofóbica, ou por motivos de vaidade nacionalista. O caso é que as árvores se conhecem pelos frutos que dão, e os frutos do monitoramento tem sido podres. Nossa subserviência não nos livrou de um endividamento exorbitante e francamente iníquos ${ }^{12}$ [...] (p. 508). (Grifos nosso)
\end{abstract}

A verdade que fica evidente na passagem acima é a necessidade de considerar que nenhuma instituição financeira internacional resolverá os problemas econômicos e financeiros dos países da periferia do sistema ${ }^{13}$ por meio da abundância dos fluxos de capitais. No entanto, para fazer frente aos resultados perversos que os recursos externos podem trazer, Rangel (2012 [1987], p. 449) traz à tona a seguinte passagem, na qual afirma que "a tomada de consciência do potencial ocioso era a esperança de um terceiro caminho, como alternativa ao comprometimento da sabedoria nacional e ao esfomeamento dos trabalhadores". Portanto, é nesta perspectiva que podemos pensar sua definição sobre os recursos ociosos e pontos de estrangulamentos existentes no Brasil.

As indústrias nos anos 1980, possuíam excesso de capacidade produtiva instalada, ou seja, estavam produzindo abaixo do seu potencial normal (reflexo da crise do choque do

\footnotetext{
${ }^{11}$ Vide as políticas econômicas adotadas no segundo mandato do governo Dilma e que foi alvo de críticas de muitos cientistas sociais. Bresser-Pereira (2016) apelidou essas políticas de "Keynesianismo vulgar" e outros como João Villaverde e José Marcio Rego (2019), afirmaram ser um “desenvolvimentismo requentado". Dito de outra maneira, tais teóricos afirmaram que as políticas adotadas pelo então governo não correspondia com a dada conjuntura político-econômica do momento.

${ }^{12}$ Publicado na Folha de São Paulo em abril de 1987.

${ }^{13}$ Como diz Paulo Nogueira Batista Junior (2019), em palestra proferida ao clube de engenharia "em relações internacionais não existe amizade, existe interesses". Nesse sentido, o autor faz referência em seu livro " $O$ Brasil não cabe no quintal de ninguém" de que a iniciativa do Novo Banco de Desenvolvimento tinha como objetivo fazer frente ao monopólio financeiro comandado a cerca de 70 anos por países do centro do sistema capitalista. Além disso, outro elemento que impõe importância no livro, é o manifesto de que o Brasil não pode ser um país desarmado, pois ele necessita fazer frente à eventuais hostilidades de países que possuem interesses diversos. Esses dois elementos podem ser caracterizados pela passagem que afirma categoricamente “[...] Ninguém vai nos defender. As mais solenes garantias internacionais não são confiáveis, muitas delas não valem o papel em que foram escritas" (2019, p. 319).
}

Revista Desenvolvimento Socioeconômico em debate v.7 n.2 (2021) 
petróleo) e devido a excessos de investimentos no ciclo anterior - fase "a". Evidenciado isto, carece pensar que se alguns setores estavam com excesso de investimentos, iam se consolidando, em contrapartida, setores com carência de investimento.

O Brasil ao desenvolver-se, naturalmente necessitou de infraestruturas para atender ao desenvolvimento gerado no período ascendente ${ }^{14}$, assim, o setor que necessitava investimento e que, por sua vez, solucionaria o problema por este desenvolvimento anterior, seria os serviços de utilidade pública, sendo que tal solução nos levaria a outro ciclo de crescimento. Porém, BresserPereira e Rego (1993, p. 111) lembram que a economia brasileira em sua essência, possui dificuldades de transferir recursos excedentes advindo do processo de acumulação dos setores ociosos para os setores mais dinâmicos e com maior possibilidade de expansão ${ }^{15}$.

O Estado brasileiro, no interregno que marca os anos 1980, estava incapacitado de financiar obras e projetos que o país carecia, cabendo, portanto, ao Estado desempenhar uma função fundamental que era de ser ao mesmo tempo poder concedente e credor hipotecário (PIZZO, 1998, p. 117). Caso o concessionário privado ficasse inadimplente, o Estado poderia fazer nova concessão, arrefecendo os impactos dessa inadimplência e não deixando as obras entrarem em processo de paralisação.

Nota-se, no entanto, que o diagnóstico não é uma simples transferência de ativos de uma empresa pública para empresa privada, como no caso da privatização pura e simplesmente, mas sim a resolução de dois problemas fundamentais: um problema econômico e outro social. $\mathrm{O}$ problema econômico seria a transferência de recursos (poupança) de um setor ocioso (setor da indústria pesada) para um setor carente de investimento (setor de infraestrutura), colocando a economia em nova onda de desenvolvimento. Já a resolução do problema social, seria a elevação dos índices de empregos na construção e manutenção das obras públicas e melhoria das condições de vida da população, resultando em ganhos reais de salários, com as diminuições dos gastos nestes serviços.

Esse diagnóstico vem na esteira da visão sui generis sobre a inflação brasileira ${ }^{16}$, o qual destoava das visões dos economistas monetaristas ortodoxos e estruturalistas heterodoxos

${ }^{14} \mathrm{O}$ Brasil no decorrer do século XX, passou por forte diversificação produtiva, o que refletiu em profundas transferência de mão de obra do setor agrário (exportador) ao setor urbano (industrial) resultando em mudanças demográficas e relações de trabalhos consideráveis.

15 Tais dificuldades encontram-se em políticas industriais claras, aliadas inevitavelmente ao setor de infraestrutura e não necessariamente às questões de sistema financeiro como no século passado, tendo em vista que o Banco Nacional de Desenvolvimento Econômico e Social (BNDES) possui fundamental relevância no que tange aos aportes financeiros nas mais variadas atividades econômicas.

${ }^{16}$ Apesar de termos consciência da relação umbilical entre nosso tema e a inflação brasileira, não adentraremos com maior profundidade no tema, devido este não ser nosso objeto principal de análise, porém, vale salientar, como era essa relação entre a inflação e a economia brasileira e qual seria o papel do Estado frente a esta situação. Em resumo, na obra A Inflação Brasileira de 1963, Rangel demostra que ela surgiu no interior do sistema econômico, dada a má distribuição de renda, ou seja, a taxa salarial nominal ser pequena. Assim, há no mercado produtos com inelasticidade-preço da demanda e outros com elasticidade preço de demanda alta. Segue-se daí, que se a renda nominal for baixa, a demanda por produtos com alta elasticidade-preço da demanda permanece praticamente inalterados, como é o caso dos produtos alimentícios, permitindo assim que seus produtos sejam arbitrariamente manipulados, pois sua demanda não deprimirá dada a elevação do preço nem que o custo de vida se eleve. Assim, produtos com baixa elasticidade-preço da demanda deixam de ser consumidos. Essas circunstâncias, segundo Bresser-Pereira e Rego (1993) faz com que o Estado ao ser pressionado pelos agentes bancários acaba por imprimir moeda, uma vez que em momento depressivo (aqui descritas fases "b" dos ciclos), o governo emite para fazer frente aos preços aumentados autonomamente pela administração das empresas e a consequente desvalorização unitária da moeda e, por outro lado faz a inflação funcionar em favor da economia. Assim sendo, ele também queria, segundo Medeiros (2017), apontar que a inflação não era o principal problema a se combater, uma vez que ela era a síndrome da recessão, pois uma anomalia existia no mercado com a oligopolização das empresas na comercialização de alimento, cujo objetivo era restringir a oferta para elevar o preço e assim defender suas taxas de lucro. O Estado, além de salvar os bancos com aumento de liquidez, mais uma vez teria papel central para resolver este problema dos oligopsônios-oligopólios que se estende por toda economia. 
cepalinos (MORENO; MODENESI, 2014). Mas qual a relação da inflação com nossa discussão? A questão a destacar é que a inflação é síndrome da recessão e, consequentemente, não o problema central a se combater. Cabe esclarecer, que uma nova rodada de crescimento econômico pressionaria a inflação para baixo, o que só seria efetivado via concessão dos serviços de utilidade pública à iniciativa privada, aliviando a política fiscal do Estado.

Qual seria, então, os passos propostos por Rangel (1987) para resolver o problema de um Estado estrangulado financeiramente e com problemas econômicos profundos? Sobre esse tema, o papel do Estado era elementar para introduzir mudanças jurídico-institucionais que viabilizassem um novo surto de crescimento. Dessa forma, no decorrer de sua obra, fica evidente a defesa de um papel ativo do Estado, enquanto organizador e direcionador de políticas voltadas a promoção desenvolvimento econômico. Neste sentido, em vários momentos de sua obra está implícita essa percepção. Paralelamente, Vilaverde e Rego (2019) dialogam com essa visão, quando analisam a presença histórica do Estado nas políticas de desenvolvimento brasileiro, mais precisamente a partir de 1940-50, período em que o Estado era impulsionador decisivo dessas mudanças qualitativas, através de políticas industrializantes via substituição de importações.

Sendo assim, Rangel (2012 [1987]) pensava os mecanismos para esta solução, passando exclusivamente pelo Estado. Assim, demonstra em seu diagnóstico que para permitir às empresas privadas concessionárias o acesso ao crédito público e privado, seria somente com aval do Estado brasileiro, com base em garantias hipotecárias sobre as instalações e equipamentos das concessionárias dos serviços públicos. Nestas circunstâncias, o Estado levaria em consideração (tendo como base de referência) o custo da execução dos referidos serviços, considerando-se a soma das despesas correntes da prestação dos serviços, a depreciação do capital fixo investido e um lucro legalmente autorizado referenciado no custo de capital, de acordo com as condições do mercado acionário e de títulos internos. Sumariamente, era esse o diagnóstico que permitiria implantar as medidas da superação da crise recessiva e a geração de um novo ciclo de crescimento.

\section{POTENCIAL DEMANDA DOS SERVIÇOS DE UTILIDADE PÚBLICA NO BRASIL: O CASO DO SETOR DE TRANSPORTE FERROVIÁRIO E RODOVIÁRIO}

O setor de transporte de cargas no Brasil possui grande potencial de recepção de investimentos, tanto para sofisticar a malha já existente, quanto para ampliá-la. Pereira (2014) lembra que a opção pela malha ferroviária data do Império, por iniciativa de Barrão de Mauá, sendo que em 1854 inaugura-se no Rio de Janeiro a primeira ferrovia. Dessa forma, as ferrovias aumentaram consideravelmente sua expansão durante a primeira metade do século XX, vindo apenas a perder espaço com a ascensão do rodoviarismo que teve seu auge a partir dos anos 1950, período em que ocorrem massivos investimentos para consolidação do modal rodoviário, tendo expressão com o Plano de Metas no Governo de Juscelino Kubitschek (1956-1960). Nesse período, houve também a implantação da indústria automobilística no Brasil.

Em relação aos investimentos no modal rodoviário em detrimento ao modal ferroviário, vale a pena recordar uma advertência feita por Rangel (2012 [1987], p. 517-519), em que nos idos dos anos de 1960, em uma conversa com um embaixador Polonês no Brasil, discutindo a questão dos transportes no país, o mesmo chamava atenção para o fato de que o transporte ferroviário, dadas as características do desenvolvimento econômico do mesmo, iria cedendo espaço à implementação das rodovias (o que estava na ordem do dia para ocorrer).

Assim, à medida em que o país se industrializava, o modal rodoviário, por sua plasticidade, tendia a quebrar os isolamentos regionais e unificar o mercado, levando as mercadorias de porta a porta, coisa que nem o transporte ferroviário nem o de cabotagem poderia 
fazê-lo. Porém, na sua percepção se aproximava o dia em que o transporte ferroviário seria imprescindível ao desenvolvimento econômico, à medida em que a industrialização e a modernização agrícola se consolidavam. Essa dinâmica desembocaria em transportes de cargas mais e mais pesadas e distâncias geográficas maiores, cujos aumentos de produtividade impetrariam a expansão das ferrovias para dar suporte a esse desenvolvimento.

A realidade atual constata a afirmação correta do autor, porque nota-se a existência da necessidade de investimentos no setor ferroviário, tendo em vista a morosidade dele, especialmente devido à perda de interesse da iniciativa privada que está associado principalmente a vultuosos investimentos em que os projetos demandam e não menos importante, aos retornos financeiros aplicados serem de longo prazo.

Em consequência, verifica-se que as ferrovias existentes se encontram em condições quase obsoleta no que concerne à renovação de frotas, expansão e modernização tecnológica. Nesse sentido, a figura 1 demostra um fato de fundamental importância, quando se trata dessa rede de transporte ferroviária, uma vez que além da expansão (novos investimentos) estar praticamente inerte devido à própria depreciação das máquinas em operação, a própria manutenção é praticamente inexiste. A figura ilustra (pela defasagem tecnológica) os baixos investimentos no que tange inclusive a restauração dos vagões e trilhos ${ }^{17}$.

Segundo dados da Embrapa (2019), os dois estados brasileiros que são mais relevantes na produção da soja são Mato Grosso e Paraná. Este último obteve altos índices de produtividade, que chegou a produzir na safra 2018/2019, cerca de 16.2 milhões de toneladas de soja, ficando atrás, apenas, do estado do Mato Grosso, que em 2019 produziu 32.4 milhões de toneladas, contribuindo para colocar o Brasil como o segundo maior produtor do grão no mundo. Tal fato contrasta com a figura a seguir e o mapa 1, devido à baixa expansão da malha ferroviária em todo o território nacional, o que dificulta o transporte de produtos como minérios de ferro e produtos agrícolas.

Figura 1 - Situação dos vagões de trens (Estação ferroviária Ferroeste, na cidade de Cascavel - PR)

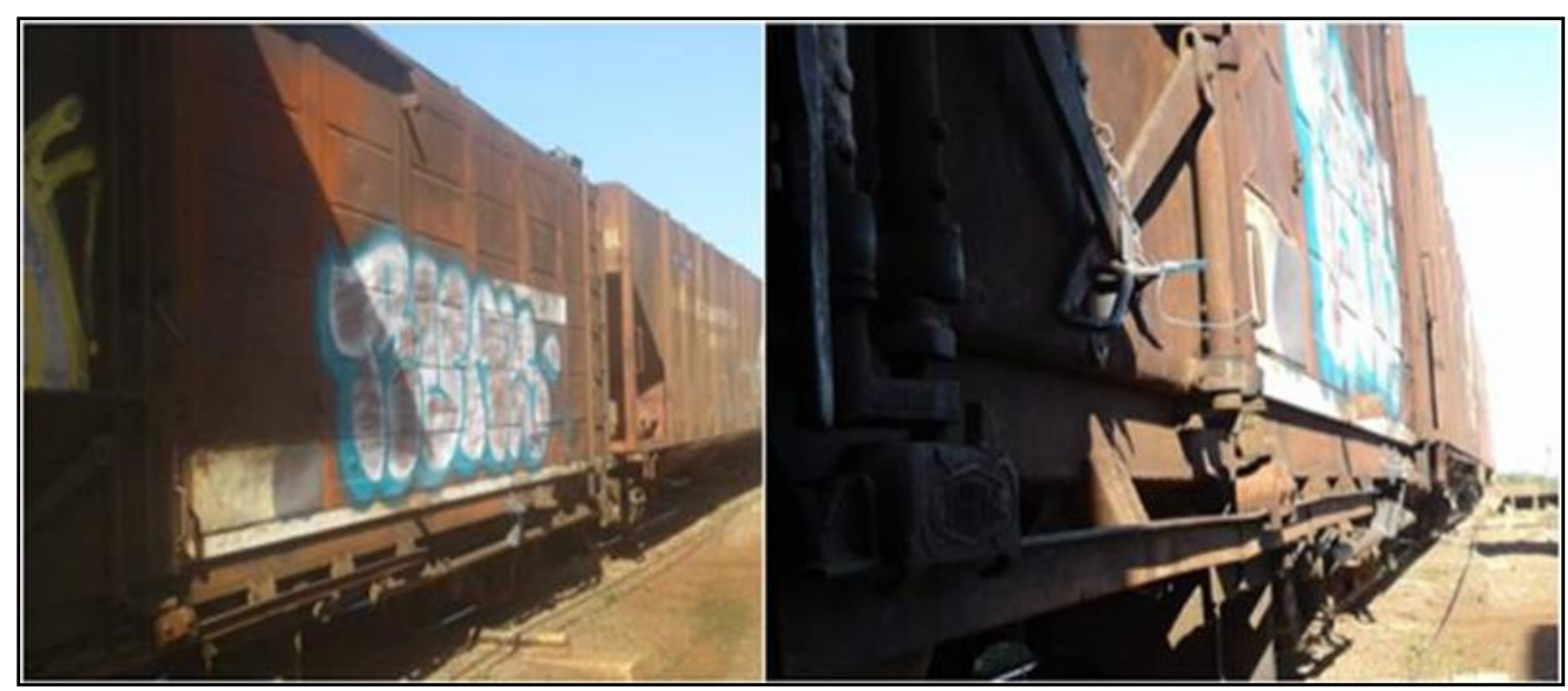

Fonte: RIPPEL (2021)

\footnotetext{
17 Segundo informações coletadas em entrevista com Fernando Pinheiro Dias - Chefe da Seção de Execução Operacional (SEXECO) - Porto de Paranaguá/PR, onde afirmou que os trens ao chegarem ao porto, muitos possuíam vários problemas com sua manutenção, pois a porcentagem de produtos perdidos no deslocamento era muito elevada em função dos inúmeros buracos nos vagões. A perda de produtos agrícolas em deslocamento, se traduz tanto no modal rodoviário, bem como no ferroviário.
} 


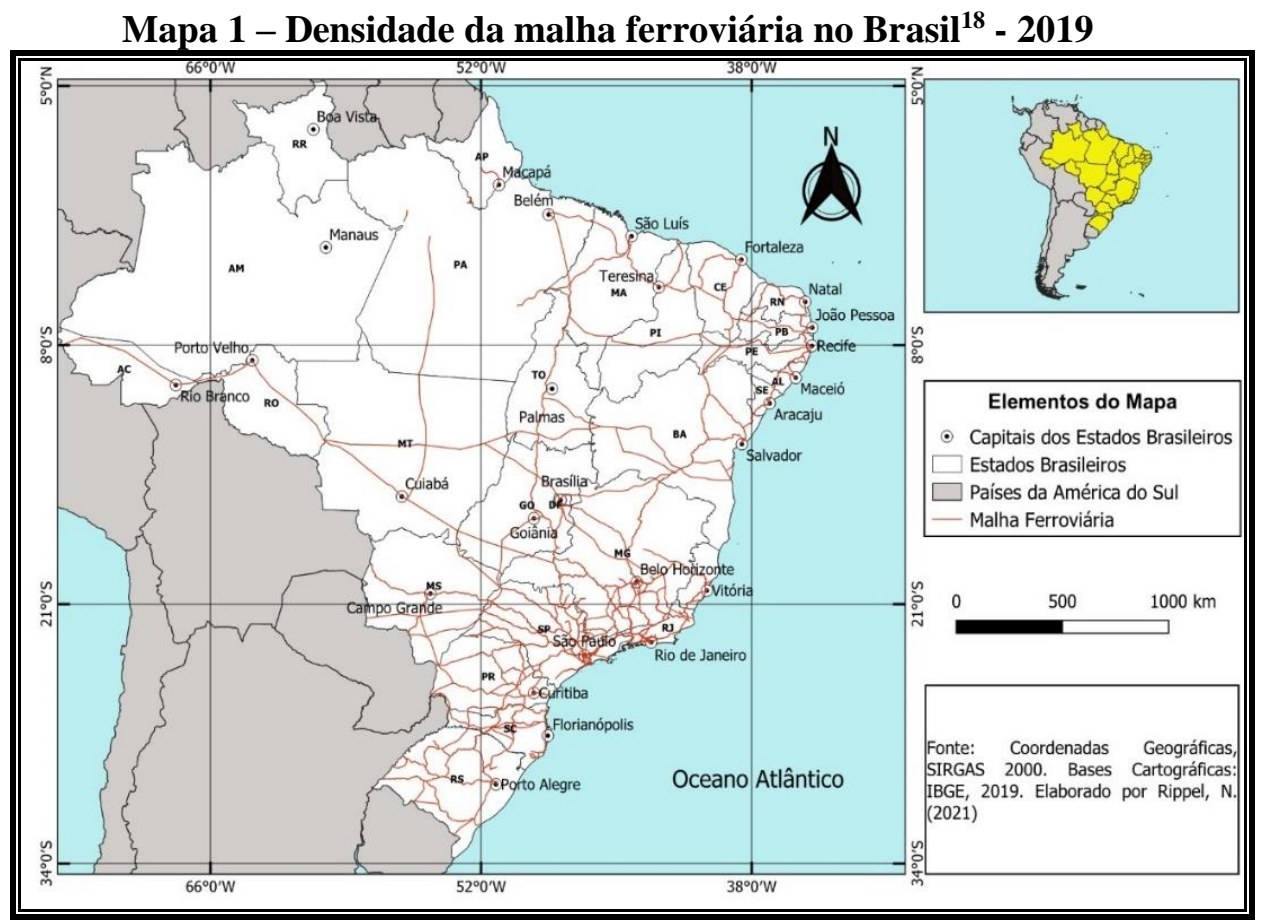

O mapa 1 evidencia os espaços vazios nas regiões brasileiras, onde os estados que possuem maior densidade da malha ferroviária são os estados do sul e sudeste, os quais atendiam especialmente a produção de café para o mercado internacional. Porém, as regiões Norte, Nordeste e Centro-Oeste, ainda se encontram com baixíssima capilaridade deste setor. Nesse sentido, a região Centro-Oeste, por ser grande produtora de commodities agrícolas (especialmente soja e milho), possui baixa expansão da malha ferroviária, assim como muitos estados brasileiros, sendo nutrida tal defasagem pelas rodovias, uma vez que de acordo com o IPEA (2010, p. 01), “o setor rodoviário brasileiro é especialmente importante pela grande participação que detém no transporte de cargas. Ao longo das décadas de 1990 e 2000, o modal rodoviário respondeu por mais de $60 \%$ do total transportado no país".

No caso do modal rodoviário, sua história no Brasil data de meados do século XIX, com a estrada "união e indústria" que ligava os estados de Minas Gerais e Rio de Janeiro ${ }^{19}$. Com isso, a consciência e engajamento de muitos políticos da época para consolidar a rodoviarização no país era bastante aguerrida. Tanto é verdade, que uma das frases do presidente Washington Luiz Pereira de Souza (1926-1930) era "Governar é abrir estradas". Em consequência, a partir de 1930 há um forte engajamento por parte do Estado para consolidar as rodovias no país. No entanto, é a partir de meados dos anos 1950, com o Plano de Metas, que há considerável aumento da malha viária simultaneamente à fabricação de veículos, como bem demonstram as tabelas 1 e 2 , respectivamente.

\footnotetext{
${ }^{18}$ Ressaltamos que o mapa foi elaborado com base nos dados "Bases georreferenciada - Ferrovias (shp) - obtidos no site do Ministério da Infraestrutura, os quais apresentam uma expansão da malha ferroviária que integram além das ferrovias em "operação" as ferrovias que estão em "Estudo" e que estão "Planejadas". Nesse sentido, por motivos de má resolução da imagem (caso transferido "o mapa Ferroviário" a este artigo), achamos relevante disponibilizarmos o link do mesmo, que está disponível em: <https://www.gov.br/infraestrutura/pt-br/centrais-de-conteudo/map-ferropdf $>$ que apresenta com maior detalhe as condições de operação da malha ferroviária brasileira.

${ }^{19}$ DNIT. Breve Histórico do Rodoviarismo Federal no Brasil. Disponível em: <http://www1.dnit.gov.br/historico/>. Acesso em: 24 jan 2021.
} 
Tabela 1 - Extensão da rede rodoviária brasileira (1955-1961)

\begin{tabular}{c|c|c|c}
\hline \multirow{2}{*}{ Especificação } & \multicolumn{2}{|c|}{$\begin{array}{c}\text { Extensão em } 31 \text { Dez } \\
\text { Ano }\end{array}$} & \multirow{2}{*}{$\begin{array}{c}\text { Diferença positiva em } \\
\text { relação aos anos em Km }\end{array}$} \\
\cline { 2 - 3 } & \multicolumn{2}{|c|}{ (Km) } & \\
\cline { 2 - 3 } & $\mathbf{1 9 5 5}$ & $\mathbf{3 5 . 4 1 9}$ & $\mathbf{1 3 . 1 6 9}$ \\
\hline Rodovia Federal & $\mathbf{2 2 . 2 5 0}$ & 9.591 & 7.215 \\
\hline Pavimentadas & 2.376 & 25.828 & 5.954 \\
\hline Não Pavimentadas & 19.874 & $\mathbf{7 7 . 2 9 3}$ & $\mathbf{2 3 . 2 4 5}$ \\
\hline Rodovia Estadual & $\mathbf{5 4 . 0 4 8}$ & 4.542 & 3.785 \\
\hline Pavimentadas & 757 & $\mathbf{3 8 6 . 8 3 8}$ & $\mathbf{3 . 4 2 2}$ \\
\hline Não Pavimentadas & 53.291 & $\mathbf{4 9 9 . 5 5 0}$ & $\mathbf{3 9 . 8 3 6}$ \\
\hline Rodovia Municipal & $\mathbf{3 8 3 . 4 1 6}$ & $\mathbf{4 5 9 . 7 1 4}$ &
\end{tabular}

Fonte: DNER Apud BNDE, 1962. Organizado por RIPPEL, N. (2021).

Tabela 2 - Produção de veículos a Motor dos Fabricantes Financiados pelo BNDE (1957-1962)

\begin{tabular}{|c|c|c|c|c|c|c|}
\hline \multirow{3}{*}{ Anos } & \multicolumn{6}{|c|}{ Unidades produzidas } \\
\hline & \multirow{2}{*}{$\begin{array}{l}\text { Total } \\
\text { geral }\end{array}$} & \multicolumn{5}{|c|}{ Fabricantes Financiados pelo BNDE } \\
\hline & & FNM & Volkswagen & Willys & Simca & Total \\
\hline 1957 & 30.70 & 3.200 & 370 & 9.291 & - & 12.861 \\
\hline 1958 & 61.129 & 3.875 & 4.818 & 15.698 & - & 24.391 \\
\hline 1959 & 96.243 & 2.079 & 16.837 & 23.824 & 1.264 & 44.004 \\
\hline 1960 & 133.078 & 2.963 & 28.358 & 39.023 & 3.633 & 73.977 \\
\hline 1961 & 145.674 & 2.678 & 47.340 & 42.599 & 5.901 & 98.518 \\
\hline 1962 & 191.144 & 1.304 & 52.993 & 61.337 & 6.904 & 122.538 \\
\hline $1957 / 1962$ & 658.018 & 16.099 & 150.716 & 191.772 & 17.702 & 376.289 \\
\hline
\end{tabular}

Fonte: GEIA apud, BNDE 1962. Organizado RIPPEL, N. (2021).

As tabelas 1 e 2 se complementam, uma vez que a produção de veículos alavancava a ampliação de estradas e rodovias no país e, por consequência, impulsionava as indústrias do setor. Essa ampliação, segundo Faro e Silva (2002 apud CAPUTO; MELO, 2009) era necessária e fundamentalmente racional, já que a capacidade instalada em 1960 ultrapassou em 17,2\% a meta fixada de 170 mil veículos. Caso a dinâmica de ampliação de rodovias não ocorresse, logo esta seria um ponto de estrangulamento e que iria contra os princípios básicos do plano que era rompê-los. Percebe-se ainda, que o aumento representou cerca de 29.240 veículos a mais da meta objetivada. Portanto, torna-se inegável (se analisarmos comparativamente) que o desenvolvimento entre ambos os setores ocorreu de maneira desigual no tempo e no espaço e que hoje sofrem do mesmo problema, que é a baixa taxa de investimentos. Os baixos investimentos resultam em inúmeros gargalos ao setor.

Ademais, segundo DNER (2001 apud IPEA, 2010, p. 01), as raízes da dependência brasileira pelo setor estão nos anos 1960 e 1970 do século passado, quando a malha rodoviária federal pavimentada teve crescimento rápido e expressivo, passando de $8.675 \mathrm{~km}$ em 1960 para $47.487 \mathrm{~km}$ em 1980. Nos anos 1980 e 1990 o crescimento foi mais modesto. Nos anos 2000 alcançou-se $56.097 \mathrm{~km}$ de estradas pavimentadas. No entanto, pode-se fazer inúmeras críticas aos planos econômicos como o Plano de Metas e posteriormente o II Plano Nacional de Desenvolvimento (II PND), mas é inegável os resultados positivos para o desenvolvimento econômico e a implantação da indústria de base no país (CASTRO; SOUZA, 2004).

Com relação à conjuntura em que seguiu o Plano de Metas, dois elementos são fundamentais: o papel do Banco Nacional de Desenvolvimento Econômico e Social (BNDES) e o papel da Superintendência da Moeda e do Crédito (SUMOC) no desenvolvimento brasileiro. 
Fica claro que o papel do BNDES não pode ser tratado como uma instituição sem importância no tabuleiro estratégico econômico, muito pelo contrário, pois sua atuação em paralelo a outros instrumentos, como obtenção de recursos externos, ampliação dos investimentos públicos e estímulo aos investimentos privados seriam as principais políticas para execução do plano (DIAS, 1996, p. 80). Entretanto, tanto o Plano de Metas, o II Plano Nacional de Desenvolvimento (PND), quanto o Programa de Aceleração do Crescimento (PAC), tiveram esse banco como um braço de sustentação essencial para expansão do setor de infraestrutura via financiamento. Observando especificamente a atuação setorial do banco no Plano de Metas, verifica-se, de acordo com BNDES (1962, p. 13), que:

Graças à sua capacidade em mobilizar e canalizar poupanças, com rapidez e eficiência, foi possível levar a cabo numerosos e importantes empreendimentos ligados aos diversos setores contemplados no Programa. Nesta fase, concentrou a sua contribuição financeira em projetos vinculados à ampliação dos sistemas de energia elétrica e das indústrias de base, embora colaborasse, também, de modo ativo, na execução de projetos relacionados com a melhoria dos sistemas de transporte e a elevação de eficiência do setor agrícola e de abastecimento, tais como: armazéns e silos, mecanização agrícola, matadouros industriais e frigoríficos.

A ampliação das redes rodoviárias no Brasil, tanto em âmbito Federal, Estadual e Municipal e suas respectivas condições de pavimentação demonstrado na tabela 1 , foi fruto do Plano de Metas, que neste caso foram favorecidos com maciços investimentos do Banco Nacional de Desenvolvimento Econômico e Social - BNDES - e estimulado pelas deficiências nos demais modais de transportes. Assim, esse transporte teve rápido crescimento, aliado não somente à recuperação e pavimentação das rodovias, mas em especial, pelo aumento da frota de veículos, demonstrado na tabela 2 , que refletiu maior demanda por rodovias em território nacional. No entanto, nota-se que entre as regiões também ocorreu um desenvolvimento desigual no processo de rodoviarização.

O mapa 2, explicita a expansão das rodovias por regiões brasileiras, cujo intuito é mostrar a espacialização das rodovias no país. Nota-se que Estados do Norte, Mato Grosso no CentroOeste e alguns estados do Nordeste possuem déficit em sua expansão, se compararmos com as demais regiões brasileiras.

Mapa 2 - Expansão das rodovias no Brasil por regiões.

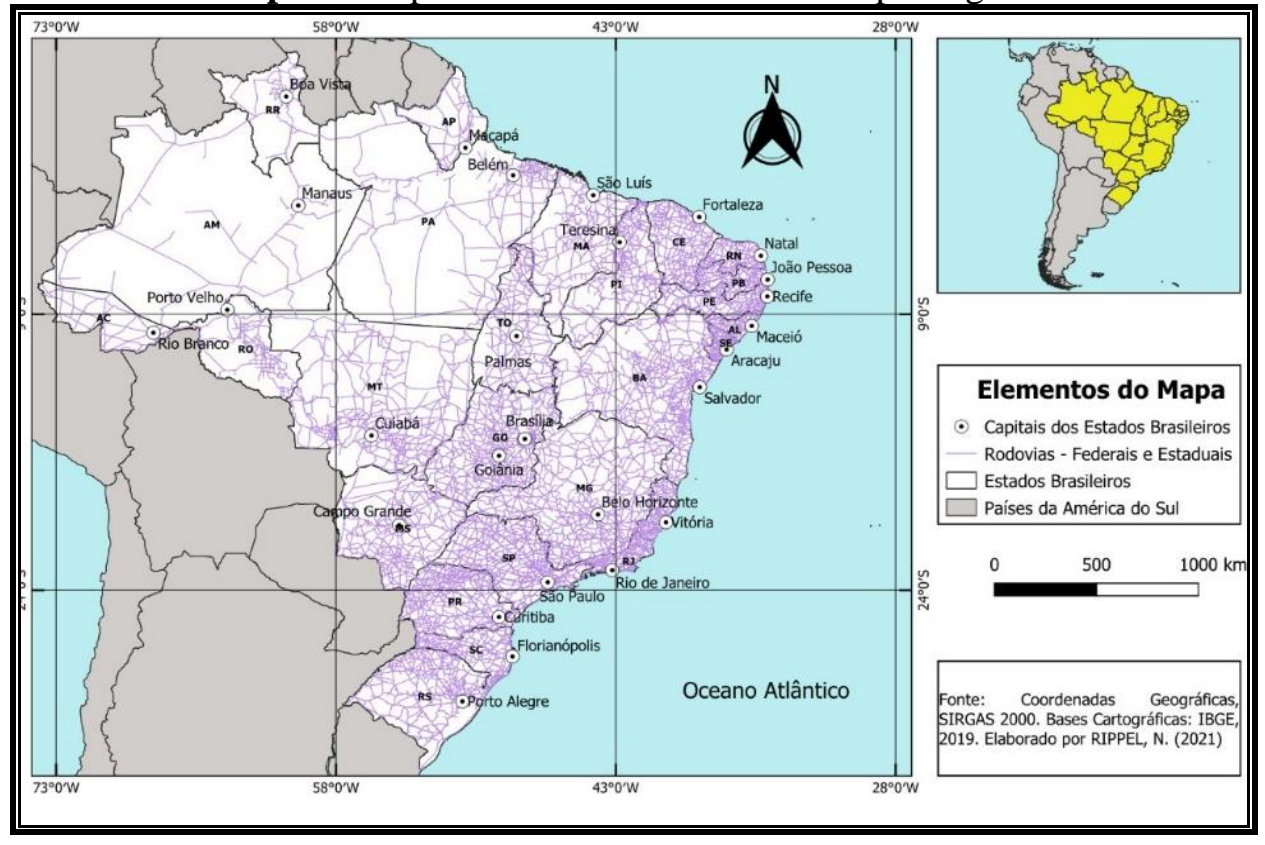

Revista Desenvolvimento Socioeconômico em debate v.7 n.2 (2021) 
Sendo assim, muitas das rodovias necessitam, além de ser restauradas, ser duplicadas, porém, desde que se atenda com maior amplitude o bem-estar da população com tarifas justas. Assim, dada as atuais condições fiscais do Estado, a ideia de concessão à iniciativa privada é uma alternativa viável para a retomada do desenvolvimento econômico, de modo que desonera gastos do Estado e impulsiona as atividades privadas. Porém, tais medidas devem ser feitas de maneira estratégica à beneficiar a população brasileira e não de forma negligente como nos anos 1990. Nesse período, tais fatos aliados às ideologias neoliberais propiciaram terreno fértil para que o Estado brasileiro passasse a adotar mecanismos de privatizações.

Deste modo, utilizando o estado do Paraná como exemplo (o qual foi reflexivo a esse processo mais geral de ideologia liberalizante), percebe-se que foi no bojo dessa conjuntura econômica que "na segunda metade da década de 1990, além dos programas estaduais em andamento, planejou-se a criação de um anel de integração que liga o polígono integrado pelas cidades-polos de Ponta Grossa, Londrina, Maringá, Cascavel e Guarapuava, que foi efetivado em 1997 [...]" SILVEIRA (2005), passando a formar uma rota logística através das concessões à iniciativa privada, na tentativa de desonerar os gastos públicos.

A interconexão entre as mais diversas regiões do estado era e é importante, e a participação privada é uma condição também necessária. No entanto, o que se coloca em questão é a forma como foram feitas essas concessões, às quais proporcionaram uma rentabilidade em demasia às concessionárias, em detrimento aos baixos retornos em termos de qualidade de vida à população. No caso do Paraná, ainda no governo Requião (2003-2010), a preocupação era em atenuar os efeitos negativos das concessões rodoviárias devido ao modelo geral de concessão possuir uma legislação que privilegia a essas empresas (SILVEIRA, 2005).

\section{OS BAIXOS INVESTIMENTO NO BRASIL}

Como já discutido, o período que se inicia a partir da década de 1980, caracteriza-se por uma queda brusca dos investimentos públicos, que não são retomados satisfatoriamente pelo setor privado, mesmo depois da estabilização e abertura econômica impulsionadas pelo Plano Real. O restante das economias da região apresenta a mesma tendência de evolução, tendo uma queda no investimento em infraestrutura de 3,7\% do PIB entre 1980 e 1985 para 1,46\% entre 2002 e 2006 (ROZAS, 2010).

Após elevados níveis de investimento no Brasil $^{20}$, realizados pelo setor público, a reestruturação econômica das décadas de 1980 e 1990 deixou uma lacuna institucional que ainda não foi preenchida satisfatoriamente pelo setor privado nem pelo próprio setor público, mesmo após a atenuação dos desequilíbrios fiscais. O investimento médio, entre 2007 e 2010, de 1,70\% do PIB, contrasta fortemente com os 4,55\% apresentados entre 1973 e 1977 (DÁlVILAFERNANDES, 2015). É verdade que o índice de 1,70\% entre 2007 e 2010 teve grande contribuição do PAC, caso contrário a situação poderia ser ainda pior.

Nesse sentido, o tema das concessões dos serviços públicos às empresas privadas transformou-se na grande aposta para a aceleração dos investimentos e a consequente viabilização de uma taxa de crescimento do produto menos modesta em comparação ao patamar que vigora após a eclosão da crise financeira internacional de 2008 (HOLANDA, 2014, p. 156157).

No entanto, a questão que se coloca é: existiram tentativas nos últimos anos, na esfera da política econômica que se aproximasse da visão de Rangel (2012, [1987])? Pode-se inferir que

\footnotetext{
${ }^{20}$ Os massivos investimentos realizados, foi reflexos especialmente pela envergadura dos planos nacionais de desenvolvimento. O Plano de Metas (1956-1961) e o II Plano nacional de Desenvolvimento (II PND) foram sem dúvida nenhuma os planos que consolidaram o Nacional desenvolvimentismo no Brasil.
} 
houve um ensaio progressista do ponto de vista das concessões a partir de 2007. Vale, portanto, ressaltar a tentativa da política econômica consolidada pelo Programa de Aceleração do Crescimento (PAC) $)^{21}$, o qual objetivava fomentar o crescimento econômico via ampliação dos serviços de utilidade pública, tendo em vista que as inversões no setor de infraestrutura são elementares para gerar efeitos multiplicativos ao conjunto da sociedade. Silveira e Julio (2013, p. 209) apontam que "quando há uma maior inversão de investimentos em obras de grande porte, como no caso das infraestruturas de transportes, há um incentivo para o aquecimento das indústrias de máquinas, matérias primas e peças", além de permitir a integração entre vários elos da cadeia produtiva reduzindo custos e melhorando a competitividade internacional.

O PAC, anunciado pelo Governo Federal em 22 janeiro de 2007, estendeu-se em duas fases: a primeira no segundo governo Lula - entre 2007 e 2010 - e a segunda fase a partir o primeiro mandato do governo Dilma - entre 2011 e 2016. ${ }^{22}$ Trata-se de um programa cujo interesse seria promover o desenvolvimento sustentável e reduzir as diferenças regionais e sociais no país. O objetivo do governo, com o investimento em infraestrutura, seria eliminar os principais gargalos do setor, ou seja, superar os estrangulamentos que impediam o crescimento econômico, isto é, as áreas potenciais de um novo processo de acumulação, viabilizando o aumento da produtividade das empresas, além do estímulo ao investimento privado e aumento das equidades regionais. Os recursos iniciais para execução do PAC tinham origem prevista nos orçamentos das empresas estatais, no orçamento fiscal e da Seguridade Social da União e provenientes da iniciativa privada (BRASIL, 2007).

A previsão, no que tange aos investimentos da primeira fase do PAC no eixo logística, era de $\mathrm{R} \$ 58,3$ bilhões e sua execução foi de $\mathrm{R} \$ 65,5$ bilhões, ultrapassando $12,30 \%$ da previsão inicial. Porém, no modal ferroviário em comparação ao rodoviário, nota-se que mesmo com um programa voltado a ampliar essa modalidade de transporte, este não foi tão satisfatório, já que a previsão em 2007 era de $\mathrm{R} \$ 7,9$ bilhões, e foi executado apenas $\mathrm{R} \$ 3,4$ bilhões, não chegando à metade do montante previsto. No caso dos portos também se vê uma situação semelhante, pois dos $\mathrm{R} \$ 2,7$ bilhões previstos em janeiro de 2007, apenas $\mathrm{R} \$ 0,8$ bilhões foram executados, ou seja, em termos percentuais, apenas $29,6 \%$ do total previsto. Embora em alguns setores os investimentos ficaram aquém do montante previsto, tais investimentos refletiram em crescimento acelerado no período (principalmente a partir de 2006). Ademais, as políticas econômicas, segundo Carvalho (2018), atuavam basicamente em três frentes: 1) o pilar da distribuição de renda; 2) o pilar do investimento público e 3) o pilar da expansão do crédito.

Além do anúncio do PAC 1, em março de 2010, ocorreu o anúncio do PAC 2, com uma leva de recursos que totalizava um montante de investimentos previstos de $\mathrm{R} \$ 1,59$ trilhão, sendo $\mathrm{R} \$ 955$ bilhões para o período de 2011-2014 e R \$ 631,4 bilhões para o período pós 2014. Esta nova fase do programa estava dividida em seis novos eixos, que abrangiam projetos de infraestrutura em todo Brasil, ficando nessa fase visível a expansão do eixo social e urbano: PAC Cidade Melhor; PAC Comunidade Cidadã; PAC Minha Casa, Minha Vida; PAC Água e Luz para Todos; PAC Transportes e PAC Energia (BRASIL, 2010, apud RODRIGUES e SALVADOR, 2011). O programa trouxe gigantescas demandas por produtos da construção civil para ampliação de inúmeros serviços de utilidade pública, o que dinamizou sobremaneira a economia brasileira naquele período, reaproximando tais setores.

\footnotetext{
${ }^{21}$ Para maiores detalhes sobre o Programa e as Parcerias Público Privadas (PPPs), sugerimos ver Lacerda (2020) livro intitulado "Devagar é que não se vai longe: Parcerias Público-Privadas e desenvolvimento econômico"

${ }^{22}$ A segunda fase do programa vai até 2016. O mesmo foi interrompido pelo golpe na então presidente Dilma Rousseff, após seu governo enfrentar inúmeras manifestações iniciadas em junho de 2013 arrastando-se até 2016, quando definitivamente o fato é consumado. Löwi (2016) afirma categoricamente que "o que aconteceu no Brasil, com a destituição da presidente eleita Dilma Rousseff, foi um golpe de Estado. Golpe de Estado pseudolegal, "constitucional", parlamentar ou o que se preferir, mas golpe de Estado."
} 
Como os investimentos em infraestruturas tiveram diminuição considerável nos anos 1990 e tendo um breve ensaio de retomada nos anos 2000 com o governo Lula e Dilma - com a política do Programa de Aceleração ao Crescimento -, tal tentativa não logrou êxito a médio e longo prazo, devido à desaceleração econômica e a Lava Jato, os quais potencializaram o golpe de Estado e a crise institucional, política e econômica, que preside nossos dias, refletindo na perca de protagonismo no âmbito dessas políticas de infraestrutura. Diante desse quadro, qual a alternativa viável? Sem dúvida, uma política que atenda o setor industrial e as infraestruturas de transportes torna-se latente para o crescimento sustentável nos próximos anos. Percebe-se, entretanto, que sua ideia acerca da concessão dos serviços públicos à iniciativa privada continua atualizada e vai continuar por um longo tempo, ao menos enquanto as políticas industriais e o setor de infraestrutura forem elementares ao processo econômico; esta última, com vistas à diminuição nos custos de produção e comercialização dos produtos industriais.

\section{RECIPROCIDADE SETORIAL ESTRATÉGICA ENTRE O SETOR DE INFRAESTRUTURAS DE TRANSPORTE E INDUSTRIALIZAÇÃO}

Os termos infraestruturas e industrialização são indissociáveis, uma vez que o primeiro setor estrangulado acarreta baixo dinamismo do segundo. Com relação a desindustrialização, grande parte da literatura ${ }^{23}$ sobre o desenvolvimento econômico admite, inclusive, a hipótese de que a economia brasileira está passando por esse processo de forma prematura e, que tem se concentrado em uma variável chamada taxa de câmbio (BRESSER; MARCONI, 2008). Portanto, se a taxa de câmbio for demasiadamente apreciada e, pior ainda, se for oscilante, a capacidade de planejamento dos industriais se deteriora e abre espaço para doença holandesa ${ }^{24}$, destruindo em consequência o complexo produtivo industrial.

É com base nessa discussão que chamamos atenção de que a destinação de recursos às áreas de infraestrutura é um elemento conciliador de uma política industrial de base, indo além dos mecanismos centrais das variáveis econômicas, como taxa de juros, taxa de câmbio e tarifas aduaneiras, mas fazendo com que tais investimentos sejam a chave de uma clara política industrial (DÁVILA-FERNANDES, 2015).

Desse modo, como a precoce desindustrialização e a obstrução do desenvolvimento das infraestruturas já é de longa data, pois trata-se de um fenômeno muito articulado com a história econômica internacional - diga-se de passagem, o consenso de Washington ${ }^{25}$ - os Estados Unidos não tardou em impor algumas restrições às políticas econômicas, tendo o auge no decorrer dos anos 1990, com imposições à abertura comercial, liberalização financeira, adesão à nova divisão internacional do trabalho e o controle em demasia do chamado tripé macroeconômico como sendo a "única política possível". Com isso, o pacto de poder que se constituiu a partir de 1930 entre o latifúndio semifeudal voltado ao mercado interno e a burguesia industrial nascente ${ }^{26}$ - foi rompido com a ascensão do novo regime de acumulação baseado no capital financeiro.

\footnotetext{
${ }^{23}$ Palma (2005); Bonelli; Pessôa, (2010); Cano, (2012); Nassif; Bresser-Pereira; Feijó (2017)

${ }^{24}$ Doença Holandesa é um termo usado por Luiz Carlos Bresser-Pereira (2008), para definir países que possuem recursos naturais em abundância e considerados baratos gerando rendas Ricardianas. Nesse sentido, ocorre que há uma sobrevalorização da taxa de câmbio em função das commodities produzidas terem menor aparato tecnológico e consequentemente menor custo de produção. A ideia original de doença holandesa, advém do fato que na década de 1960, a Holanda ao descobrir gás natural teve um afluxo de divisas estrangeiras que provocou a valorização de sua moeda.

${ }^{25}$ Termo cunhado por John Williamson, para designar um pacote de medidas macroeconômicas e que os países da América Latina adotaram como receituário.

${ }^{26}$ Sobre o pacto de poder constituído a partir de 1930 sugerimos a leitura de Rangel (2012 [1981]) intitulado "A história da dualidade brasileira".
} 
O pacto, então formado, não objetiva a produção da economia real para o aumento do dinamismo econômico interno, uma vez que a burguesia industrial não ascendeu como sócio maior. Os reflexos econômicos e sociais dessa formação pactual são irreparáveis. Do ponto de vista de longo prazo, é necessária uma guinada desenvolvimentista que eleve a produtividade paralelamente à empregabilidade da mão de obra que compõe o exército industrial de reserva, porém, levando em consideração os conflitos de interesses na macroeconomia, que na teoria novo-desenvolvimentista não tem relevância (MEDEIROS, 2017).

Faz-se necessário pensar a relação recíproca entre tais setores, cujo setor de infraestrutura correspondem a ativos de base essencial sobre os quais se desenvolve toda e qualquer atividade econômica produtiva, sendo determinantes sobre os fluxos do comércio internacional e geradores de economias externas (SÁNCHEZ, 2010). Contudo, há urgência em investimentos em infraestrutura econômica, saneamento básico, transporte, comunicação e energia, pois possui enormes possibilidades de expansão, o que demanda forte produção do setor industrial, onde nas palavras de Silveira (2002, p. 75),

[...] Quando se inicia uma obra do porte de uma ferrovia, há o aquecimento das indústrias de máquinas e de equipamentos ferroviários e, consequentemente das indústrias de peças e de matérias-primas e do comércio e serviços. Envolve-se todo um sistema. Haverá, portanto, efeito multiplicador por vários ângulos, contemplando toda a macroeconomia nacional. Keynes e seus discípulos desenvolveram cálculos para identificar o grau de atuação do efeito multiplicador em vários setores de infraestruturas $[\ldots]$.

Ou seja, os efeitos multiplicadores internos tornar-se-ão visíveis, pois a mão de obra qualificada, que será absorvida, tende a ser elevada, em consonância ao aumento da produtividade que poderá ser paralelo ao aumento dos salários, tendo um desenvolvimento sustentado de longo prazo.

Mas o que explica tal desaceleração econômica da última década? O que ocorre é que a quarta dualidade prevista por Rangel (2012 [1980]) não se efetivou, ou seja, o sócio menor do pacto de poder se acovardou ${ }^{27}$ diante do capitalismo financeiro internacional. Como não liderou o pacto, passou a ser cúmplice das políticas neoliberais de austeridades fiscais. Muitos ainda, além de abandonar as políticas industriais, passaram a financeirizar-se $\mathrm{s}^{28}$.

Fica evidente, portanto, que a crise econômica e política que persiste no Brasil, em especial a partir de 2015 e que possui sua etiologia no centro do sistema capitalista, com a crise de 2008 nos Estados Unidos, fez saltar aos nossos olhos a mão de obra desocupada e as baixas taxas dos investimentos em Formação Bruta de Capital Fixo (FBCF). Como a utilização da capacidade instalada em períodos de recessão decresce, acaba por elevar consequentemente o índice de desemprego, uma vez que nos modos de produção capitalistas as crises são inerentes ao sistema, tendo no mundo do trabalho as consequências imediatas e mais visíveis do processo, uma vez que o desemprego é o reflexo primário (RAULINO, 2015, p. 69).

No gráfico extraído do IBGE - Pesquisa Anual da Indústria da Construção - o qual apresenta a evolução dos empregos formais no país, nota-se que o auge da ocupação ocorreu em 2013, com cerca de 961.338 pessoas e que em 2018 a ocupação cai para 547.642, ou seja, uma perda de 413.696 postos de trabalho.

\footnotetext{
${ }^{27}$ Nas palavras de Mamigonian "Eu costumo dizer que os industriais brasileiros são extremamente competentes e extremamente agressivos do ponto de vista empresarial. Mas são absolutamente covardes, medrosos, incompetentes do ponto de vista político". MAMIGONIAN, Armen. "Esta é a segunda crise depressiva do ciclo longo". Fundação Maurício Grabois; Junho de 2010. Depoimento a Osvaldo Bertolino [mimeo].

${ }^{28}$ Os "investimentos" passaram a ser mais rentáveis em aplicações financeiras com as políticas de juros altos do que investimentos em setores produtivos da economia.
} 
Portanto, desocupação da mão de obra é um sério problema que hoje nos assola. Inclusive, Rangel (2012, p. 239) afirma que "[...] não é possível usar a capacidade ociosa do capital sem usar paralelamente a capacidade ociosa do trabalho, isto é, sem engajar mão de obra, sem ampliar a folha de salários. Ora, mais salários importarão necessariamente em mais consumo". Estes consumos incidirão em última instância na maior utilização da capacidade instalada, o que gerará maior demanda por emprego.

Gráfico 01 - Pessoal ocupado no setor de infraestrutura 2009-2018

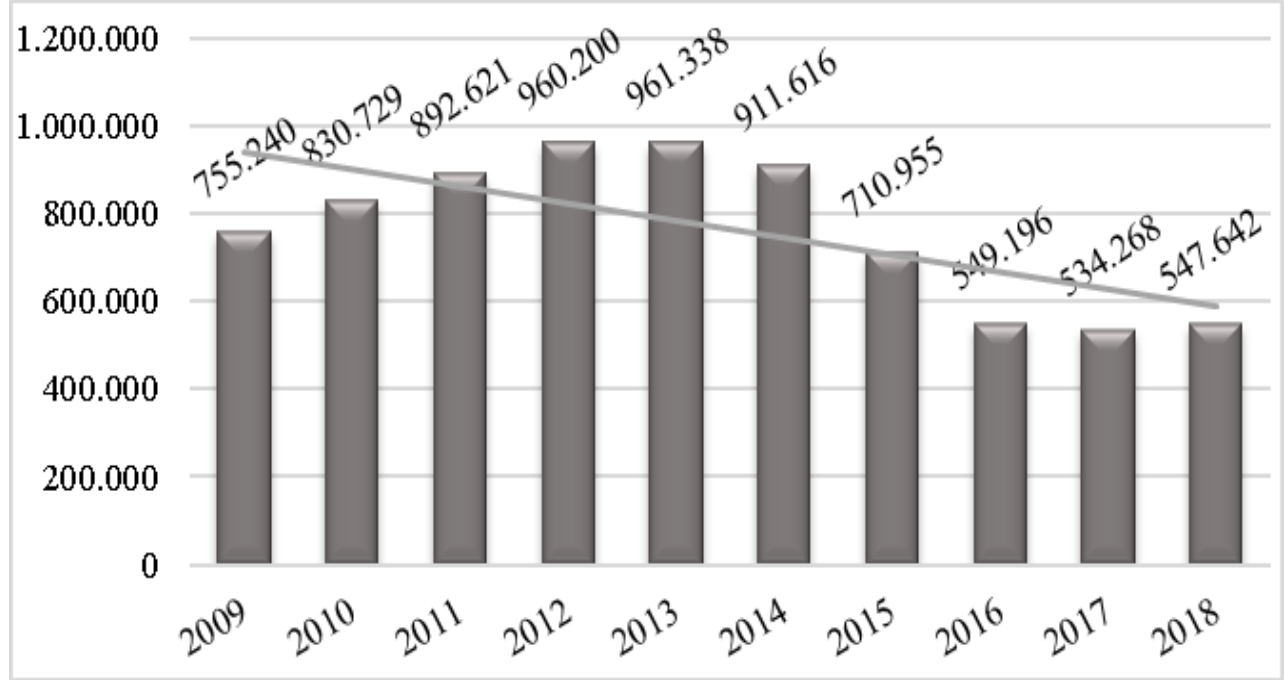

Fonte: IBGE. Elaborado com base na Pesquisa Anual da Indústria da Construção

Cabe destacar que essa variável negativa do emprego não se restabelecerá enquanto os investimentos na Formação Bruta de Capital Fixo (FBCF) não se efetivar de forma estável, ou mesmo a economia ter uma retomada de crescimento, tendo como base o setor de infraestrutura. Não obstante, a partir do momento em que há maior demanda do setor da construção civil, para suprir as obras inerentes aos setores de infraestrutura, as indústrias não necessariamente necessitam investir em expansão de suas plantas, dado que esse potencial instalado já existe.

Com relação aos investimentos, segundo dados das Contas Nacionais Trimestrais IBGE, os investimentos tiveram queda constante a partir do terceiro trimestre de 2013, vindo a ter ligeira retomada no terceiro trimestre de 2018, 2019 e 2020, respectivamente. As ameaças de retomada indicam que não serão sustentáveis a médio e longo prazo, pois o país ainda não conseguiu recuperar os índices do terceiro trimestre de 2013. Nota-se que a ocupação de mão de obra acompanhou a mesma tendência dos investimentos. Nesse sentido, concordamos tanto com Lange (1986) quanto Mazucato (2014) ${ }^{29}$, os quais trazem excelentes contribuições para o debate acerca da importância do Estado como mola propulsora do desenvolvimento econômico, seja ele liderando investimentos ou mesmo liderando propostas e projetos nos vários segmentos setoriais.

\footnotetext{
${ }^{29}$ Mariana Mazucato é autora do livro “O Estado Empreendedor: desmascarando o mito do setor público vs. privado". O livro traz em seu âmago a importância do Estado empreendedor - "leonino" - em "empurrar" e não apenas "cutucar" o setor privado - "animais domesticados" - a investir. No decorrer de seu livro, a autora traz inúmeros exemplos pelo mundo em que o Estado foi mola propulsora de desenvolvimento por meio de Bancos estatais com financiamento de longo prazo. Os exemplos são países como: Alemanha, China, Japão, Estados Unidos e Brasil. O livro destaca ainda, o papel ativo desempenhado pelo Estado na geração do crescimento puxado pelos investimentos em inovação, uma vez que o setor privado, evita lançar-se a intentos dessa magnitude devido às incertezas de sucesso. Mas mesmo que tenha sucesso tal inovação, o retorno é a longo prazo o que é um grande fator de desestímulo.
} 
Mazucato (2014, p. 26-29), referindo-se ao Estado aponta que:

[...] a maioria das inovações radicais, revolucionárias, que alimentaram a dinâmica do capitalismo - das ferrovias à internet, até a nanotecnologia e farmacêuticas modernas aponta para o Estado na origem dos investimentos "empreendedores", mais corajosos, incipientes e de capital intensivo. [...]. Um Estado empreendedor não apenas "reduz os riscos" do setor privado, como antevê o espaço de risco e opera corajosa e eficientemente dentro desse espaço para fazer as coisas acontecerem. De fato, quando não se mostra confiante, o mais provável é que o Estado seja "submetido" e se curve aos interesses privados. [...]

Portanto, o Estado não deve ser tratado como um ente abstrato, deslocado e exógeno à sociedade, mas sim como uma instituição integrada à dinâmica econômica social, dotado de capacidade que vai além da visão contracíclica de atuação quando a demanda agregada e investimentos privados encontram-se demasiadamente baixo. Quando essas circunstâncias se instalam, o Estado pode atuar através de diversas forma e com diferentes mecanismos e um desses mecanismos é o investimento público via bancos de desenvolvimento. Esses bancos possuem destaques quando o assunto é financiamento de longo prazo, uma vez que bancos como o BNDES por exemplo, é um forte protagonista no sentido de realizar empréstimos com juros muito baixos e a longo prazo, realizando por sua vez, um papel que o setor privado renuncia em fazê-lo.

Por fim, com base no exposto e nos dados apresentados, indica-se urgentemente a retomada da capacidade de investimentos em infraestrutura, inclusive porque tais investimentos nesse setor passam a ser indutores dos investimentos privados, gerando emprego, ampliando o consumo e aumentando o nível de utilização da capacidade instalada nas indústrias. A chamada simbiose entre ambos os setores. Porém, há um detalhe proeminente nesse debate: a Proposta de Emenda Constitucional (PEC) aprovada em fins de 2016, que impede investimento público por 20 anos em inúmeras áreas, é um ponto crucial a se resolver, uma vez que a mesma ainda não foi revogada pelo atual governo. Enquanto o terrorismo fiscal não deixar de existir e a Emenda Constitucional do Teto de Gastos não ser revogada, o desenvolvimento econômico dificilmente voltará ao horizonte da nação brasileira.

\section{CONSIDERAÇÕES FINAIS}

O intuito deste breve texto foi aprofundar o debate sobre as ideias de Ignácio Rangel, evidenciando sua originalidade e a atualidade do seu pensamento acerca da importância do Estado na liderança do desenvolvimento e a aproximação do setor industrial junto ao setor de infraestrutura, onde este último corresponde a ativos de base essencial para a retomada do desenvolvimento industrial. Contudo, torna-se fundamental retomar o debate acerca do crescimento econômico que há algum tempo caiu em desuso do ponto de vista prático, pelos elaboradores das políticas econômicas, ficando retoricamente apenas a preocupação com a estabilização econômica. Dessa forma, cabe pensar estrategicamente a simbiose entre o setor de infraestrutura de transporte em adesão às políticas industriais, visando o aumento de produtividade com absorção de mão de obra qualificada, uma vez que os investimentos nesse setor podem ser utilizados como instrumento de promoção do crescimento da renda per capita, instrumento de promoção tecnológica e de fortalecimento das relações exteriores, sobretudo comerciais.

Faz-se necessário também uma política cambial compatível e estável, que rompa com a política instituída nos anos 1990, derivada do consenso de Washington e, a partir disso, adotar as políticas mais viáveis. Enquanto política nacionalista/progressista, torna-se urgente o Brasil 
retomar essa visão de Projeto de Desenvolvimento Nacional que indique para onde o país deve seguir, caso contrário, qualquer caminho poderá se tornar aparentemente útil e viável.

\section{REFERÊNCIAS}

BATISTA JUNIOR, P. N. O Brasil não cabe no quintal de ninguém: Os bastidores da vida de um economista brasileiro no FMI e nos BRICS e outros textos sobre nacionalismo e nosso complexo de viralata. São Paulo: Le Ya, 2019, p.448.

BONELLI, R.; PESSÔA, S. de A. Desindustrialização no Brasil: um resumo da evidência: Texto para Discussão Nº. 7. Rio de Janeiro: IBRE/FGV-RJ, 2010.

BRESSER-PEREIRA L. C.; MARCONI, N. Doença Holandesa e Desindustrialização. Valor econômico. 2009. Disponível em:

〈http://www.bresserpereira.org.br/Articles/2009/09.11.25.Doenca_holandesa_e_desindustrializacao.pdf $\rangle$. Acesso em: 15 dez de 2019.

BRESSER-PEREIRA, L. C. Rangel: Ciclos longos e dualidade. 2006. Disponível em:

<http://www.bresserpereira.org.br/papers/2006/06.15.Rangel-CiclosLongosEDualidade.pdf >. Acesso em: 14 dez de 2019.

BRESSER-PEREIRA, L. C.; RÊGO, J. M. Um mestre da economia brasileira: Ignácio Rangel. Revista de Economia Política, v. 13, n 2 (50), abril-junho/1993. Disponível em: $<$ http://www.rep.org.br/pdf/506.pdf> Acesso em: 14 dez de1993.

CANO, W. A desindustrialização no Brasil. Economia e Sociedade, v. 21, n. Número Especial, p. 831$851,2012$.

CAPUTO, A. C.; MELO, H. P. de. A industrialização brasileira nos anos de 1950: uma análise da instrução 113 da SUMOC. Estud. Econ. [online]. 2009, vol.39, n.3, p.513-538.

CARVALHO, L. Valsa brasileira: do bom ao caos econômico. São Paulo: Todavia, 2018.

CASTRO, A. B. de.; SOUZA, F. E. P. de. A economia brasileira em marcha forçada. Rio de Janeiro: Paz e Terra, 1985.

CASTRO, M. H. M. de. Nosso Mestre Ignácio Rangel. Disponível em: <http://www.contrapontoeditora.com.br/arquivos/detalhes/Rangel\%20Introducao15-30.pdf >. Acesso em: 20 jun de 2018.

DÁVILA-FERNÁNDEZ, M. J. Desindustrialização e o investimento em infraestrutura como instrumento conciliador de uma política industrial base no Brasil. Revista de Economia Política, vol. $35, n^{\circ} 3$ (140), p. 576-600, julho-setembro/2015.

DIAS, J. L. de M. O BNDE e o plano de metas. In: Banco Nacional de Desenvolvimento Econômico e Social (Brasil). O BNDES e o plano de metas. Rio de Janeiro: Banco Nacional de Desenvolvimento Econômico e Social, 1996. p. 81-136.

GUIMARÃES, C. A dualidade brasileira de Ignácio Rangel. Revista de Economia Política, vol. 14, nº 4 (56), outubro-dezembro/94. 
HOLANDA. F. M. de. O desafio das concessões de serviços de utilidade pública: Atualidade do pensamento de Rangel. In. Ignácio Rangel: decifrador do Brasil. Felipe Macedo de Holanda, Jhonatan Uelson Pereira Sousa de Almada, Ricardo Zimbrão Affonso de Paula (Organizadores). São Luís: Edufma, 2014.

LANGE, O. Ensaios sobra planificação econômica. Política econômica: princípios e planejamento. São Paulo: Nova cultural, 1986.

MAMIGONIAN, A. O enigma brasileiro atual: Lula será devorado? In: Ciência Geográfica. Bauru, n. 10, vol. 10 (2), maio/agosto de 2004. (atualizado em 2019)

MAZUCATO, M. O estado empreendedor: desmascarando o mito do setor público vs. setor privado. $1^{\circ}$ ed. São Paulo: Portfolio-penguin, 2014.

MEDEIROS, M. C. Pactos de poder e política econômica: comparações Brasil-China. Geosul, v. 32, n. 63, p 269-286, Florianópolis, jan./abr. de 2017.

MORCEIRO, P. C. Desindustrialização na economia brasileira no período 2000-2011: abordagens e indicadores. São Paulo: Cultura Acadêmica, 2012.

NASSIF, A.; BRESSER-PEREIRA, L. C.; FEIJÓ, C. The case for reindustrialisation in developing countries: towards the connection between the macroeconomic regime and the industrial policy in Brazil. Cambridge Journal of Economics, v. 42, n. 2, p. 355- 381, 2017.

PEREIRA, V. de B. Transportes: história, crises e caminhos. $1^{\text {a }}$ ed. Rio de Janeiro: Civilização Brasileira, 2014. p322.

PIZZO, M. R. O pensamento de Ignácio Rangel. Armen Mamigonian e José Marcio Rego (Orgs.). - São Paulo: Ed. 34, 1998. p176.

RANGEL, I. M. Obras Reunidas. Vol. 1 e 2. Rio de Janeiro: Contraponto: Centro Internacional Celso Furtado de Políticas para o Desenvolvimento, 2012.

RAULINO, I. Abertura Comercial, Crise e Reestruturação Produtiva na Grande Empresa Têxtil do Médio Vale do Itajaí: Mitos e Verdades. In. Cadernos Geográficos. $n^{\circ} 15$ Florianópolis. Departamento de Geociências, 2015.

RIPPEL, N. Recursos ociosos e pontos de estrangulamentos no setor de infraestrutura de transporte no estado do Paraná. Dissertação (Mestrado em Geografia). Universidade Estadual do Oeste do Paraná - Campus de Francisco Beltrão-PR, 2021.

RODRIGUES, T. A.; SALVADOR, Evilásio. As implicações do Programa de Aceleração do Crescimento (PAC) nas políticas sociais. SER Social, Brasília, v. 13, n. 28, nov. 2011. Disponível em: <http://seer.bce.unb.br/index.php/SER_Social/article/view/5624/4672 >. Acesso em 20 set 2020.

ROZAS, P. Problemas y desafíos en el financiamiento de la infraestructura en América Latina. Revista de la CEPAL, Santiago de Chile, nº101, p.59-83, agosto de 2010.

SÁNCHEZ, R. J. (2010). Algunas reflexiones sobre losservicios de infraestructuraen América Latina. Textos para discussão CEPAL/IPEA, n 25 , Brasil.

SILVEIRA, M. R. Concessões de serviços públicos à iniciativa privada e o governo lula: o caso ferroviário. Anais do X Encontro de Geógrafos da América Latina - 20 a 26 de março de 2005 Universidade de São Paulo. Disponível em: 
<http://observatoriogeograficoamericalatina.org.mx/egal10/Geografiasocioeconomica/Geogra fiaeconomica/44.pdf > Acesso em: 04 maio de 2020.

Transporte e logística: as ferrovias no Brasil. Geosul, v.17, n.34, 2002.

SILVEIRA, M. R.; JULIO, A. S. Os investimentos em transportes do Programa de Aceleração do Crescimento (PAC) e o efeito multiplicador brasileiro a partir do governo Lula da Silva. Journal of Transport Literature, vol. 7, n. 4, pp. 199-224, 2013. Disponível em:< https://www.scielo.br/pdf/jtl/v7n4/10.pdf >. Acesso em: 15 jun de 2020.

VILLAVERDE, J.; REGO, J. M. O novo desenvolvimentismo e o desafio de 2019: Superar a estagnação estrutural da economia brasileira. Revista de Economia Política, vol. 39, n 1 (154), pp. 108127, janeiro-março de 2019.

Sites:

BNDES. Banco Nacional de Desenvolvimento Econômico e Social. Exposição sobre o Programa de Reaparelhamento Econômico, 1962. Biblioteca digital. Disponível em:

<https://web.bndes.gov.br/bib/jspui/?locale=pt BR >. Acesso em: 26 nov de 2020.

BRASIL. Ministério do Planejamento. Programa de Aceleração do Crescimento. Disponível em: <http://www.pac.gov.br/ >. Acesso em: 29 out de 2020.

CNT. Confederação Nacional do Transporte. Pesquisa CNT de rodovias 2019. Disponível em: <https://pesquisarodovias.cnt.org.br/ >. Acesso em $15 \mathrm{dez}$ de 2020.

DNIT. Departamento Nacional de Infraestrutura de Transporte. Breve Histórico do Rodoviarismo Federal no Brasil. Disponível em: 〈http://www1.dnit.gov.br/historico/ >. Acesso em 13 jan de 2020.

EMBRAPA. Soja em números (safra 2019/20). Disponível em:

〈https://www.embrapa.br/soja/cultivos/soja1/dados-economicos >. Acesso em: 20 jun de 2020.

IBGE. Instituto Brasileiro de Geografia e Estatística. Taxa de Investimento. Contas Nacionais Trimestrais. Disponível em: <https://www.ibge.gov.br/estatisticas/economicas/comercio/9300-contasnacionais-trimestrais.html >. Acesso em: 13 jan de 2021.

PAIC 2018: Indústria da construção sofre com a queda nas obras de infraestrutura e nas contratações do setor público. Disponível em: $<$ https://agenciadenoticias.ibge.gov.br/agencia-sala-deimprensa/2013-agencia-de-noticias/releases/27793-paic-2018-industria-da-construcao-sofre-com-aqueda-nas-obras-de-infraestrutura-e-nas-contratacoes-do-setor-publico>. Acesso em $01 \mathrm{fev}$ de 2020.

IPEA. Instituto de Pesquisas Econômicas Aplicadas. Rodovias Brasileiras: Gargalos, investimentos, concessões e preocupação com o futuro. Eixos do desenvolvimento Brasileiro, 2010. Disponível em: $<$ http://repositorio.ipea.gov.br/bitstream/11058/5305/1/Comunicados_n52_Rodovias.pdf $>$. Acesso em: 08 jan de 2020.

Recebido: 17/02/2021

Aceito: 20/09/2021

Publicado: Dezembro de 2021 